\title{
TUDOMÁNYTÖRTÉNET
}

\section{Fejezetek a 19. századi nyelvemlékkiadás történetéből* Döbrentei Gábor és a Régi Magyar Nyelvemlékek}

1. 1838-ban jelent meg a nyelvészeti szemléletü szövegkiadás első nagy vállalkozása, a Régi Magyar Nyelvemlékek címü sorozat. A kiadvány története szorosan összeforr szerkesztője, DÖBRENTEI GÁBOR nevével. Méltatói a modern nyelvemlékkiadás megteremtőjeként tisztelik, nyelvemlék-kiadási elvei lényegében ma is helytállóak.

E jeles évforduló kapcsán tüztem ki feladatomul meglévő ismereteink összerendezését, felidézve Döbrentei Gábor pályájának fontosabb mozzanatait, valamint a korabeli források alapján igyekeztem rekonstruálni a Régi Magyar Nyelvemlékek megjelenésének körülményeit.

2. 1785. december 1-jén született a 19. századi irodalom- és nyelvtudomány egyik legérdekesebb és legellentmondásosabb alakja, Döbrentei Gábor.

Amikor a személyével és munkásságával kapcsolatos tudománytörténeti szakirodalmat fellapozza az olvasó, igen változatos kép fogadja. Az 1926-os Magyar Irodalmi Lexikonban a következőket olvashatjuk: „[...] izgat és serénykedik, de fáradozásait nem kíséri siker, személye iránt nem ébred barátságos vonzalom, tevékenységéből kiütközik önző hiúsága, hiúságából kevély önhittsége, uralkodásra való törekvése, amivel Kazinczyt is elriasztotta, az Auróra-kör komoly, önzetlen munkásságú vezéreit pedig annyira maga ellen ingerelte, hogy nemcsak a Conversations-Lexikon pörben érte igazán érzékeny támadás és vereség, hanem akadémiai törekvései terén is" (VÁNYI szerk. 1926: 217).

A későbbiekben sem változik sokat a megítélése: „Nagy müveltségü, de csekély tehetségü író; rendkívül sokat dolgozott és sokféleképpen akart az irodalom és a közélet hasznos szereplője lenni, de tetteit sokkal inkább a törtetés, mintsem az őszinte ügybuzgalom jellemezte" (BENEDEK szerk. 1963: 264).

Mivel érdemelte ki ezt az ellenszenvet, amellyel a „hálás utókor” méltatja munkásságát? Az okok messzire nyúlnak: JANCSÓ ELEMÉR - Döbrentei életrajzírója - szerint Kazinczy halála után azok, akik Döbrenteivel együtt rágalmazták az irodalomszervezőt, ellene fordultak, és őt támadták. „Már ekkor megszületett a vád ellene, hogy Kazinczyval szemben igazságtalan és hálátlan volt és ez ellen a vád ellen hiába védekezik. Haláláig elkíséri és utána is kísért emléke ellen" (JANCSÓ 1944: 90).

Úgy tünik, az irodalomtörténet egyoldalúan Döbrenteit marasztalja el ebben a pörlekedésben, holott az egymás rágalmazása mögött személyes ellentétek feszülnek. Kifogásolták Döbrentei kétszínűségét, udvaronc szellemét, arisztokrata összeköttetéseit, azonban Kazinczy sem volt tárgyilagos. A két nagyon hiú ember vetélkedéséből a kisebb tekintélyü Döbrentei került ki vesztesen. változata.

* A Magyar Nyelvtudományi Társaságban 2010. október 19-én elhangzott előadás kibővített 
Ma már azonban árnyaltabb Döbrentei megítélése. 2005. december 5-én a Magyar Tudományos Akadémia emlékülést tartott születésének 220. évfordulóján. Az ünnepségen KISS JENŐ méltatta DÖBRENTEI müveltségszervezői munkásságát, megemlítve a magyar nyelv ügyében kifejtett tevékenységét is (2006: 8-13).

Ilyen előzmények után talán nem érdektelen vállalkozás némi figyelmet szentelni ennek a kanyargós életútnak.

Kora ifjúságát Kemenesalján töltötte. Apja Döbrentey Lajos, evangélikus prédikátor, 1799-től Bobán volt evangélikus lelkész, 1802-től pedig a kemenesaljai egyházmegye esperese. Iskoláit Pápán, a református kollégiumban kezdte, majd a soproni evangélikus líceumban folytatta. Irodalmi érdeklődése hamar megmutatkozott, a soproni tanulók magyar egyesületének (Magyar Társaság) először könyvtárnoka, majd titkára lett. A társaság tagjainak müveiből 1804-ben kiadott emlékkönyvben jelentek meg első versei.

1806-ban sok változás történt az életében: pesti utazása során megismerkedett Virág Benedekkel és Révai Miklóssal, majd májusban beiratkozott a wittenbergi egyetemre de még odaútja során Bécsben felkereste Batsányi Jánost és Báróczi Sándort is. 1806 őszétől már Lipcsében folytatta tanulmányait. A két egyetemen világtörténetet, esztétikát, lélektant, poétikát, klasszika-filológiát, jogot és szentírás-magyarázatot hallgatott, közben francia, olasz és angol nyelven tanult.

Amikor Németországból visszaérkezett, Kazinczy ajánlatára Oláhandrásfalván (Küküllő megye) gróf Gyulay Lajos gyermekeinek nevelője lett. Az itt eltöltött idő alatt megismerkedett az erdélyi szellemi élet jeles képviselőivel: Aranka Györggyel, Cserey Farkassal, Gyarmathi Sámuellel, Bolyai Farkassal. Barátságot kötött Wesselényi Miklóssal, s vele, valamint néhány ifjú arisztokratával nagy körutat tett Olaszországban (1814). Hazatérőben meglátogatták Berzsenyit Niklán, Kisfaludyt Sümegen, Dukai Takács Juditot Dukán, Kis Jánost Sopronban.

Az elkövetkező évek során egyre jobban kiteljesedett sokrétü irodalmi és tudományos munkássága. Széles körü levelezést folytatott írókkal, politikusokkal, különböző tudományszakokban munkálkodó tudósokkal, müvészekkel. A korabeli lapokban sorra jelentek meg cikkei és tanulmányai. Kolozsváron négy évig (1814-1818) szerkesztette az Erdélyi Múzeum c. folyóiratot, 1819-ben kidolgozta az Erdélyi Magyar Tudós Társaság tervezetét. 1820-tól Pesten telepedett le (SzINNYEI 1893: 1033-1036; BENEDEK szerk. 1963: 264).

1825 szeptemberében megismerkedett Széchenyi István gróffal. Hamarosan jó viszonyba kerültek, így nem meglepő, hogy a pozsonyi országgyülés után a Nemzeti Kaszinó és a lóversenytársaság jegyzője lett Döbrentei. A bizalmas viszonyt igazolja az is, hogy Széchenyi - mások mellett - hozzá is elküldi a készülő Hitel fejezeteit „,csiszolgatásra" 1829-ben. Mivel DöBRENTEI a megjegyzéseit a kéziratra írta, így tudhatjuk, hogy mit javított, illetőleg mit írt át. A stiláris javítások mellett például rendszeresen kijavította az iktelen alakban használt ikes igéket, kommentárt is füzött a javításhoz: „NB. A melly ige ik-be megyen ki a praesens 3-dik személyében mint gazdálkodik (és nem gazdálkod), annak imperfectuma a Conjuctivusban ék azaz gazdálkodnék és nem gazdálkodna, az imperativus pedig ál, azaz gazdálkodjál és nem gazdálkodj." DöBRENTEI többször kijavította a számnév utáni többes szám alkalmazását is: „A magyarban a szám u. m. tíz, harminc, hány, sok, kevés már magában foglalja a többes számot, azért nem így száz emberek, hanem száz ember s. a. t. nem hány birtokosok, hanem hány birtokos" (VISZOTA 1916: 60-61). Széchenyi a többes szám használatára vonatkozó javításokat általában elfogadta, 
de az iktelen formát meghagyta, és összességében nemigen vette figyelembe DÖBRENTEI javaslatait. A baráti viszonnyal magyarázzák sokan azt is, hogy 1828-ban részt vehetett a Magyar Tudós Társaság (Akadémia) alapszabályait kidolgozó országos küldöttségben. 1830-tól a Társaság filozófiai osztályának rendes tagja, 1831-től négy éven át titkára is.

Mint író eleinte Kazinczy köréhez tartozott Döbrentei, a nyelvújítás híve volt, s csakúgy, mint Kazinczy, az irodalom fellendülésétől várta a nemzet újjászületését. Szóalkotásai közül többet ma is gyakran használnak, például a történelem szavunk is töle származik. A budai hegyvidék neveinek visszamagyarosításában is elévülhetetlen szerepe volt: 1844-ben a Honderü címü újságban vetette fel a névváltoztatás gondolatát (DÖBRENTEI 1844: 141-142). Ezt követően Visszamagyarosítás Budapesten címmel írt cikksorozatot az elnémetesedés folyamatáról, és történeti fejtegetéseiben javaslatot is tett magyar elnevezésekre (1844: 335-336, 1845a: 489-491, 1845b: 21-23). 1847-ben ötvenhat - valójában budai - név magyarosítását kezdeményezte (magyar névvel való ellátást) a budai elöljáróságnál. A közgyülés 1847. június 11-i ülésén teljes egészében elfogadta a beadványt A magyar nevek propagálására és ünneplésére „dülőnévkeresztelő”-t tartottak 1847 júniusában ([PETRICHEVICH] 1847: 499; VÉRTESY 1972: 100; BALÁZS 2006: 73-78). Döbrenteinek köszönhetjük többi között Pasarét, Gazdagrét, Csillebérc, Rézmál, Tündérhegy, Szemlöhegy, Kelenföld, Vérhalom, Kurucles, Sasad, Németvölgy elnevezéseket. Természetesen voltak olyan nevek is, amelyek nem maradtak fenn.

Az elnevezéseket a korabeli közönség hamar elfogadta, noha a német nevek többségének már akkor is volt magyar megfelelője. Döbrentei sikere abban rejlett, hogy jó érzékkel fordult a nemzeti pátoszhoz, nyúlt vissza a történelmi hagyományokhoz. Törekvése illeszkedett a reformkor nemzeti függetlenedési mozgalmaihoz (PoGÁNY 1969: 205, 1973: 197).

Az 1820-as évek végére Kazinczyhoz füződő szoros barátsága felbomlott, ugyanis Kazinczy szintén vágyott az akadémiai titoknokságra (titkárságra). 1829. április 2-án ezt írja Kazinczy Döbrenteinek: „Te engem úgy hurczolgatsz mint Nyelvtöröt, mint Czivakodót. Hiszem hogy igazán Nyelvtörőnek nézsz; ismerlek, 's vártam azt tőled de az engem nem bánt: hogy irigy Czivakodónak nézhetnél nem hihetem; ismered forró keblemet, melly az igaz érdemet, ha ifjú, ha szegény emberben találja is, örvendve vallja érdemnek, 's az illyennek még kevélykedik barátságával; az efféle vádat eredeti bünöd téteti veled, melly hajlékonnyá tész azt a' szint játszanod, a' mit czéljaid kívánnak, a' ritkán tiszták. Téged elszédíte az a 'magad által is reményleni soha nem mert nagyság, hova mesterségeid juttatának el, nem érdemeid. De miként feledheted te, hogy az én hajlandóságom nélkül legfeljebb is egy falusi papocska levél vala, nem nagy talentumod 's talán még kevesebb tudománykád többet nem igen igérhetének; vagy mint testvérid Vas- és Bors-áros? Minekutána Septemberben rád ordítám a’ mit szemtelen garázdaságod belőlem kisajtolt, most pedig nyomtatásban rád hányt szabdalásim rád ijeszthetének, nem tartok többé hogy pályámon beléd lehessen botlanom: de töled annál inkább várhatom, hogy a'mit ellenem rég ólta üzsz, s' már Pozsonyban is, most még dühösebben fogod. Itt vagyok tehát, elszánva mindenre, nevezetesen arra, hogy véres betükkel festem homlokodra a'mit érdemlesz, ha elégtételt nem kapok - azt a' fogadást, hogy gaz suttogásid nekem és azoknak, a' kiket én tisztelek, szeretek, békét hagynak." (VÁCZY 1911: 38-39).

1830-ban irodalmi tekintélye mélyen megrendült a Conversations-Lexikon-i pörben játszott ellenszenves viselkedése miatt. Ezt követően Döbrentei kihúzta magát a nyílt harcokból. - Tevékenyen részt vett a színi kultúra hazai megteremtésében, hozzájárult a magyar 
dramaturgia kibontakozásához. Lefordította Molière A fösvény és Shakespeare Macbeth címü darabját. Egyike volt a magyar ifjúsági irodalom megteremtőinek: írt ábécéskönyvet és elbeszéléseket is gyermekek számára. 1842-ben - sok önkényes változtatással - három kötetben kiadta Berzsenyi összes müveit.

1844-ben királyi tanácsossá nevezték ki. 1851. március 28-án halt meg Budán; az Akadémián 1851. május 26-án Toldy Ferenc tartotta felette a gyászbeszédet (SzINNYEI 1893: 1036-1044).

3. E sokat vitatott pálya talán legértékesebb, legidőállóbb alkotása az 1838 és 1846 között gyüjtött és kiadott nyelvemlékek-sorozat. A magyar nyelv állapotára a felvilágosodás eszméinek terjedése irányította az érdeklődést. Felismerték, hogy a szellemi élet csak akkor lendülhet fel, ha müvelése a majdan mindenki számára érthető anyanyelven történik. „Minden nemzet a maga nyelvén lett tudós, de idegenen sohasem” - írta Bessenyei György 1778-ban a Magyarság című cikkében, sürgetve az anyanyelven való művelődés lehetőségének megteremtését.

A századforduló reménytelen éveiben a politikai, társadalmi mozgalmak helyett is felértékelődik a nyelv kérdése. A nyelv a nemzeti identitás hordozója, de már előtérbe kerülnek specifikus funkciói, középpontba kerül az irodalmi nyelv fejlesztése, benne a művelt ízlés meghatározó szerepe, az írók újítási joga, a nyelv megőrizendő nemzeti karakterének kérdése.

A reformkor a magyar politikai és szellemi élet lassú, folyamatos, de rendkívül jelentős átalakulásának időszaka. Az 1820-as évektől a magyar irodalom- és nyelvtörténetben alapvető változások történtek. Kazinczy és körének újító törekvései nyomán változott az irodalom nyelve. Egyre általánosabbá vált az árnyaltabb kifejezésekre alkalmas irodalmi nyelv, mely a népköltészet elfogadásával a népnyelv által is gazdagodott. A nyelvújítástól kezdve már nemcsak történeti értékük van a régi magyar szavaknak és szövegeknek, hanem fontosakká válnak a nyelvfejlesztő törekvések, és később a nyelvtudomány számára is (SZENTPÉTERY föszerk. 2000: 129-130, 166).

A történelmi források feltárása és közreadása Magyarországon a 17-18. század fordulóján indult meg. A század közepétől jelennek meg azok a forráskiadványok, amelyeket máig számon tartunk: Bél Mátyás, Pray György, Katona István, Kovachich Márton György munkái. A folyamat két kiemelkedő mozzanata is a Halotti beszéd kiadásához köthető. A modern nyelvemlék-filológia előfutárának Sajnovics János Demonstratio (1770) címü müve tekinthető. A kötet tartalmazza a HB. betühü közlését, Faludi Ferencnek a korabeli nyelvre áttett olvasatát, Sajnovics latin fordítását és kommentárokat.

Hasonlóképpen korának, és a korai nyelvemlékkiadásnak kiemelkedő vállalkozása Révai Miklós Antiquitatesa (1803). A Halotti beszéd betűhű közlése mellett olvasatot, latin fordítást, kommentárt és filológiai megjegyzéseket tett közzé, rávilágítva Sajnovics módszertani hibáira.

Az 1830-ban megalakuló Magyar Tudós Társaság (a későbbi Akadémia elődje) intézményes keretet adott a magyar nyelv ápolásának: az Akadémia célja az „Alaprajz” szerint az, „hogy munkálkodása által hazánkban a’ tudományok és szép müvészségek honni nyelven míveltessenek" (MTTÉvk. 1: 101). Az MTT első és legfontosabb feladata a nemzeti nyelv múvelése, ezért elhatározták a magyar nyelv nagyszótárának és grammatikájának elkészítését. 1832-ben a harmadik nagygyülésen hangzik el: „lappangó régi magyar 
kéziratoknak ha lehet eredetiben megszerzését, ha nem, leghívebb lemásoltatása megindítását [...], melyekből a’ nagy szótárhoz sok elavult, de jó magyar szavakat; a’ grammatika tekintetében sok nevezetes régi magyar szerkezetet 's beszédejtést lehetne kiszedni” (MTTÉvk. 1: 88). A Tudós Társaság Rendszabásainak I. 2-4. pontja a nyelv ápolásának feladatait fogalmazza meg: ,2. A’ hazai nyelvet egész gonddal csínosabbá és gazdagabbá fogja tenni; 3. Azt mint eredeti munkák’ dolgozása, mind régi és új remek írások’ magyarra tétele által gyarapítja; 3 . E' végre bármelly oklevelet, egyéb emléket és még rejtve lévő kéziratot felkeresvén, a’ tudományok díszére szolgálandókat köz ismeretbe hozza" (MTTÉvk. 1: 111-112). Szintén ezen a nagygyülésen terjeszti elő javaslatát a történettudományi osztály, hogy történelmünk oknyomozó feltárását elősegítse: 1. a hazai könyvtárakban rejtőző kéziratokat felkutatása, külföldi utazások a fontos könyvtárakba - Bécs, Graz, Prága, Milánó, München -, listát kérni a magyar tárgyú iratokról és lemásolni, majd kútfők gyüjteményében kiadni; 2. eredeti oklevelek gyüjtése; 3. külföldi múzeumok megkeresése, magyar tárgyú oklevelek másolása (MTTÉvk. 1: 94).

Több irányból, különböző céllal, és igen nagy buzgalommal megindult a nyelvemlékek gyüjtése. Az 1833. április 10-i heti ülésen Vörösmarty Mihály javaslatára elhatározzák a nyelvemlékek nyelvészeti szemléletü kiadását, hogy azokban a nyelvtudós vizsgálhassa a nyelv változását.

A negyedik nagygyülésen megfogalmazott kiadási elvek ma is elfogadott tudományos követelmények: 1. A kézirat 16. század előtti legyen (ezt később 1550-re változtatták). 2. Hasonmást adjanak minden különbözö kézírás egy lapjáról; a szöveget mai betűkkel írják át, de az eredeti helyesírással; „Elől pedig utasításul a’ régi ábécze mai olvasású betűkkel magyaráztassék, 's az elavult szavak és szószerkezetek kijegyeztessenek." 2. Előbeszéd fejtse ki a kézirat leírását, és amennyire ki lehet nyomozni, történetét (MTTÉvk. 2: 32).

Az első felhívásnak már megvan az eredménye: a nagygyülésen ismertetik Luczenbacher [Érdy] János 162 régi magyar nyelvemléket tartalmazó listáját.

A Tudós Társaság ötödik nagygyülésén, 1834-ben „Megállítaték a’ már bégyültek’ kiadásának meg is kezdése, nagyobb 4ed rétben, 300 példánnyal. 'S az, azokhoz tartozó ismertetések' szerkesztetése és nyomtatásukra való gond, szavazat' többségével, az Igazgatóság által meghatározandó tiszteletdíj mellett, November 10d. Döbrentei Gábornak adatott, melly ülés az első kötet' czímét 's foglalatját így határozta: Régi Magyar Nyelvemlékek. Kiadja a' magyar tudós társaság. Döbrentei Gábor felügyelése alatt" (MTTÉvk. 2: 77). A tervek szerint az első kötetek - mai elnevezésüket használva - a Halotti beszédet, a Bécsi kódexet és a Czeh-kódexet tartalmaznák. Jankovich Miklós felajánlotta, hogy a második kötetet saját költségén jelenteti meg a tulajdonában lévő nyelvemlékek anyagából. Kár, hogy a nagylelkü gesztus soha nem valósult meg.

Az Akadémia első titkáraként tevékenykedő Döbrentei Gábor nagy lelkesedéssel látott munkához. Kiterjedt levelezést kezdett az ország levéltáraival, fontosabb múzeumaival, felszólította a külföldön dolgozó tudósokat a magán- és állami könyvtárak, levéltárak anyagának átnézésére, ő maga is utazott, másolt, gyüjtött. Időközben azonban le kellett mondania az Akadémián betöltött titkári tisztségéről. A király 1834. április 17-én budai kerületbeli első helyettes tartományi biztossá nevezte ki, és ez nem fért össze a titoknoki állással. Vélhetően ismét valamiféle összetüzés húzódik meg a lemondás mögött, ugyanis a leköszönő beszédében ezt mondja: „Álljon a’ koszorú akarki’ fején, csak mienk, csak 
nemzetünké legyen a' míveltségi győzelem. Részemről én, mindig utáltam olly indúlatot, melly önszeretet' megsértésén, inkább az egészet is, az elébb ohajtottat, kevély gázolással tapodja; mert illy dölyfösek, megint hátrébb vetik azon megeredést, miért víni elébb sok erőnek kellene" (MTTÉvk. 2: 90-91).

Ha bármiféle sérelem is érte, munkája kárpótolta. Két év múlva már így ír barátjának, Bolyai Farkasnak: „Sokszor elfoglala elmémet két előbeszéd, melyet a bécsi Codexhez (1382-1430) és Kanizsainé imádságaihoz írok. Összehányok ezek miatt minden Franciscanus, Paulinus évkönyvet, nagyokat kaczagok a fraterek ösztövéritésén s kinzásán és mérgelődöm az emberi nem ostobaságain. Egyébiránt a »Régi magyar nyelvemlékek« szerkesztését örömestebb viszem a titoknoki hivatalnál, melyet felette meguntam volt. Majd meg, néha rest voltam. El-elgondolék jó barátaimmal lefolyt időmre, akarék is irni, mint Neked is, de csak haladott. Buda, November 4. 1836" (KonCz 1897: 449).

A levélben emlegetett Czeh-kódex az egyik első nagy felfedezés. Czeh János történész 1833-ban az érsekújvári ferencesek könyvtárában találta meg, és már 1833 augusztusában értesíti Döbrenteit (ABAFFY 2000: 341). Ö számol be az 1833. október 16-i heti gyülésen a felfedezésről, és a Czeh-kódex mellett az Érsekújvári kódex leírása is szerepel az évkönyvben.

A hatodik nagygyülésen, 1835-ben, már konkrét tervekről és folyamatban lévő másolásokról számol be Döbrentei. Titoknoki közbenjárásra Szalay Ágoston 1835. június 24-én kelt levele szerint hajlandó átengedni 400 eredeti magyar levél (1504-1560) közlését, azzal, hogy a kötetbe „Szalay Ágoston’ gyüjteménye” címmel kerüljön be, és tiszteletdíjként szabad kiosztással bizonyos számú példány adassék (MTTÉvk. 3: 22-23). A gyüjtemény - mint tudjuk - később önálló kötetben jelenik meg.

Titkári jelentésében azt kéri Döbrentei, hogy küldje el az Akadémia Jászóvárra és Leleszre, a két ősmonostorba és az útba eső könyvtárakba. Dessewffy József és Teleki József elnök hivatalos megkeresésre ugyanis azt a választ küldte Richter Alajos jászói prépost, hogy ugyan 1550 előtti időkből nem talált semmit, de 1559., 1560., 1568. és 1575. évekből van magyar nyelvü irat a konvent levéltárában. Döbrentei fellelkesülve a jó híren, és a szükös anyagi körülményekre tekintve, nem kíván több útiköltséget a felénél, mint amibe kerül (MTTÉvk. 3: 22). Érkezése előtt József nádor főherceg értesíti a szerzeteseket az akadémiai megbízottról, és utasítja öket, hogy bocsássanak minden iratot Döbrentei rendelkezésére, hogy azokat hites konventuálisok jelenlétében áttanulmányozhassa. 1835. október 16-án érkezik Jászóvárra, és kezdetét veszi a több éves munka (GoRzó 1914: 8-9, 59-60).

A jászói és a többi levéltárban végzett kutatásairól a hetedik nagygyülésen, 1836-ban részletesen beszámol (MTTÉvk. 3: 95-141). Mint írta, a konventben Fedák Pál főjegyző előkészítette az anyagot számára, ,de én szemtanú vágytam lenni magam, 's kezdék megtekinteni elejétől fogva mindent, ha találnék-e az elegyesek (miscellanae) csomójában valami hajdani magyar levelet, nyugtatványt, végrendeletet; a’ határjárások (metales), így a' toldalékok (appendicum fasciculi) között magyar okiratot, vagy nem tünnék-e elé a' sok latin bevallás' (fassio), ajándékozat' (donatio), iktatás' (statutio), parancs' (mandatum) pergamene' hátán némelly magyar tartalom, oda vetve korából” (MTTÉvk. 3: 95).

Itt, és a majdan meglátogatott levéltárakban is igyekezett saját maga átvizsgálni az anyagot, és felmérni, hogy mióta van magyar nyelvủ írásbeliség, meddig tartott a csak latin kor. Gyüjtését kiterjesztette a 17-18. századra, és egyébként is feljegyzett minden említésre méltó adatot. 
A jászói levéltárban tizenkét napot töltött, és az ottaniak szívélyes hozzáállását jól érzékelteti, hogy Richter Alajos prelatus átvállalta a kiválasztott iratok másolási költségeit (MTTÉvk. 3: 141). Sokszor nem is a hatalmi szó, hanem apróbb figyelmességek lendítették tovább a munkát. A hetedik nagygyülés beszámolójára készülve báró Fischer Norbert alperjeltől várt bizonyos anyagokat: „Cserneczky kassai könyvkereskedő idejövén, azt gondolám, magával hozza a jászói irományokat. Hanem, hiszem, a mi nyúlik, nem múlik, elfogja azokat küldeni a Báró Úr, más biztos alkalommal, ugy-e bár, nem sokára? Azért várom, mert addig tudósításom megírásához jegyzeteimből nem foghatok. [Új bekezdés.] Mind gondolkodtam mivel kedveskedjem viszont a Méltóságos Úrnak. Végre, gondolám, talán szívesen olvas verseket, azért íme, kölcsönös barátságom külső jeléül gróf Teleki Ferenc verseinek küldöm emlékezetül egy példányát” (GORZÓ 1914: 43).

Az iratokat megkapva nem maradt el a dicséret sem: „,Tegnap kaptam a jászói gyönyörűen elkészült másolatokat. Egészen elálmélkodtam a' tiszta, csinos íráson. Mennyi örömöm van 's ezt a' Báró Úrnak kell köszönnöm és ugyan szívemböl is írom köszönetemet. Lehetetlen, hogy a' m. t. társaság ülése is, midőn beadom majd, hasonló örömre, köszönetre ne fakadjon. Zsinek levéltárnok Úr, a’ mint látom, szerénységből [nem] tette ki nevét. Én tehát saját kezemmel írtam fel [a’] legutolsó tiszta levélre” (GoRZÓ 1914: 45).

A beszámolójában név szerint említi azokat a levéltárosokat, jegyzőket, akik segítették munkáját. Úgy tünik, könnyen szót értett a különböző rangú hivatalnokokkal, és elnyerte jó néhány nemes támogatását is. Kassán például, amikor gróf Forgács Istvánnal találkozott, az megígérte, ha Nógrádba megy, betekintést kap a levéltárába: „Erede gondolám ez abból, mert ohajtottam eloszlatni mindenütt azon bizonyos tartózkodást, minél fogva, nem minden birtokos hajlik eléadni levéltárát. Családi jogok, 's elegyedések' okleveleit a'magyar akadémia, mondám, kutattatni nem akar, a' levéltárnok csak azon magyar okiratokat terjessze elé, mellyeket hite megenged; ki nem adhatóról pedig, legalább azt mutassa meg, hogy magyarul van, kivált, ha XVdik százszak’ végéig lévő volna. Ezen elv szerint azonban világosságra lehet bocsátani, historiai, diplomaticai, hézagokat pótoló többféle adatot is, hanem ez, megint másnemü vizsgálat lenne” (MTTÉvk. 3: 110).

Munkáját nemcsak a gyanakvás, hanem a mostoha körülmények is hátráltatták. Októberben indult útnak, és a rossz időjárás miatt több helyre nem jutott el. A levéltárak sem voltak mindig alkalmasak a téli kutatásra. Gyöngyösön a ferenciek könyvtárában a „Rendkívüli hideg miatt, lehetetlen volt benne sokáig keresgélnünk. Ígéré hát maga [Magócsy István quardian] tenni azt kikelettel” (MTTÉvk. 3: 113). Máshol, mint például a pozsonyi városi levéltárban, azért nem nézhette végig az anyagot, mert rendezetlen volt, nem is lehetett megállapítani, mikortól vannak magyar iratok. A következő években is folytatta fáradhatatlan munkáját: levelezett, utazott, másoltatott. Részletesen beszámolt a nyolcadik (1837) és a kilencedik nagygyülésen (1838) is arról, hogy milyen anyagot kapott, hol járt, mit kapott ajándékba, és ki végezte a másolást.

Nemcsak szerkesztője, gyüjtője volt az iratoknak, hanem értő olvasója, filológusa is. Egy Vas megyei utazása kapcsán jegyzi meg beszámolójában: „Eszembe forga itt megint, hogy külön régi családoknál hajdanibb iralmakat, még pedig nyelvünk tiszti divására, házi élet festésére nézve sokkal érdekesebbeket találhatnánk, mintsem káptalan 's konvent levéltárában, mert a' magyar nyelvnek törvényi eljárásokba vételét a' világi rend maga között kezdé, folytatá, 's ennek öntanultsági szelleme, melly öt, az iráshoz elébb kellett pap segedelme alúl kivevé, jelent meg vele a' káptalan és konvent előtt, és ez kíváná 
majd, hogy a’ pap, egyházi magyar irásoktol megválva, ugy nevezett világi tárgyakat is magyarúl fogadjon el, vagy magyarúl kezdegessen feltenni. A' tanítványok' utódai, mestereik utódain, kitevének. Miért? Egyik szelleme, helytt állás: másiké, fejtő mozgalom” (MTTÉvk. 4: 69).

1838-ban megjelent az első kötet:

„Időkör A' magyar keresztyénedés elejétől minden, a’mi 1550-nig eredetiében elé kerül Már 1550-től 1575-ig némi válogatással 1575-1600-ig még nagyobb megválasztással Döbrentei Gábor felügyelése alatt Budán 1838.

Temetési beszéd és könyörgés [Halotti beszéd és Könyörgés]

Ótestamentomi néhány könyv [Bécsi kódex]

Öszvesen 493 lap, 8 hasonmás, finom velinen, kemény tábla, papiros borítékban.”

A Halotti beszéd jegyzeteire különösen büszke Döbrentei. Még szerkesztés közben megpróbálja tisztázni Horvát István felvetését, miszerint a nyelvemlék bencés eredetü, és saját feltevését is, hogy Jászó környékéről származik. Ezért megkérte a jászóiakat, hogy a kódex néhány szavát gyüjtsék a környéken: „Szól-e így a jászói v. debregyi ember: megszokosztja, e’ helyett megszakasztja. Értik e' ezen szavakat: fesz, önőttei, bírságnap, tilott, üldet kinzat. Mondják é' háromszor helyett hármul? hijában v. híjával helyett héon? Nem forog e fenn e' szó náluk: isa? 's ha igen, mit teszen?” (GoRZÓ 1914: 53).

Fischertől a következő választ kapta: ,igen örömest tellyesétettünk tekéntetes Úrnak kivánságát. De a' legnagyobb szorgalom mellett is nem többet tudhattam ki, mint a' menynyit ide mellékelve küldöm tekéntetes Úrnak. [...] való igaz, hogy a' Debrődi de tsak az őregeknél divatozik azon szó megszokottja, hármul, heón, de isa szóval nem emlékezik senki” (GORZÓ 1914: 36). A levélből kiderül, hogy összeállítottak valamiféle adatsort, de Döbrentei nem használta fel a kiadásnál.

Szeder Fábiánhoz írt leveléből megtudhatjuk, hogy mit tart különösen fontosnak a tanulmányában: „1. Ezen első kötet többféle uj 's megállható világítást ad elé; többfélében pedig kérdéseket támaszt, 's ha el nem dönti is a' históriai valót, megmozgatott mindent 's igy elébbre vihetővé tette az ügyet, legalább mások által. 2. Ha a' Temetési beszéd előtti XLII. 's XLVI-d lapon lévőkre kegyedtől felvilágosításokat nyernem szerencsém leszen, nagy köszönettel fogadom a' LXXII.d lapon álló befejezésem értelmében. Azt hiszem példányát adtam annak, miképpen kell, illik tudományos tárgyról szólva, mások nézeteit csenddel, tisztelve elmondani, 's ujakat gorombaság 's hetykeség nélkül eléállítani; 's e' tónust akkor, midőn literaturánk mezején borzasztó baltázások folynak! [...] Buda, okt. 26. 1838." (RÉCSEY 1899: 484).

Az Előbeszédben megismétli az 1835-ben kidolgozott, és a Társaság által elfogadott nyelvemlékgyüjtési és -kiadási elveket. E szerint a nyelvemlékek gyüjteménye ne csak nyelvújítási példatár, hanem filológiailag megbízható forrásgyüjtemény is legyen a nyelvtudomány több ága (összehasonlító nyelvészet, nyelvtörténet, nyelvmüvelés), valamint a paleográfia és a helyesírás-történet számára. Az egyes nyelvemlékekről betühív átiratokat kell készíteni, s ehhez lehetőség szerint csatolni kell a nyelvemlék keletkezéstörténetét, a szerzőjéről, a kor müveltségéről összegyüjtött ismereteket, az elavult szavak, szószerkezetek jegyzékét és nyelvtani megjegyzéseket, továbbá el kell készíteni a nyelvemlék első oldalának hasonmását. A kódexeken kívül nyelvemléknek kell tekinteni minden egyéb témájú levéltári forrásanyagot is. DÖBRENTEI nyelvemlék-kiadási elvei a mai forráskiadványokban is visszaköszönnek. 
Ugyan több helyen is találkozhatunk azzal a véleménnyel, hogy DÖBRENTEI paleográfiai hüségre törekedett (SZABÓ 1948: 129; BÁRCZI 1961: 417), a szabályzatból azonban kiderül, hogy ezt csak a hasonmások esetében követte, ilyen igény a szövegkiadásnál nem várható el. Ma ezt a fajta szövegközlést betühü átiratnak nevezzük.

Az első kötet megjelenésével párhuzamosan nyomtatták a második és a harmadik kötetet, és folyt tovább a gyüjtés is. Ez pedig most sem zajlott probléma nélkül. 1839-ben Győrben járt, az ott tapasztalt nehézségekről a 2. kötet előszavában is beszámol. A fennmaradt levelek szerint Döbrentei pontosan meghatározta kívánalmait az iratok lemásolására vonatkozóan. Szerette volna elérni, hogy „kedveskedésből” másolják le az iratokat, de ettől elzárkózott Sütő József őrkanonok, és a szabott másolási díjakat is nehezen fogadták el. Nem csoda, ha a jegyzőhöz írott levele végén így csattan fel: „Megkell vallanom, sehol sem járt ennyi bajjal a' kiválasztottak leiratása, és sehol a' 13 hely között, hol jártam, a' dij körül ennyi beszéd, irás, nem volt, mint a győri káptalannál. Vagy kedveskedésül tevék, vagy kimondá a' leiro mit kiván ’s azonnal eligazitottam" (JENEI 1959: 521).

Hasonló nehézségekkel kellett megküzdenie erdélyi útja során is. 1841-ben Hunyad megyében gyüjtött, és engedélyt kapott Wachsmann János szász ispántól a szász levéltár anyagának másolására. Megígérték, hogy elkészítik a kért anyagot. „Tizennyolc hónapja éppen most az érzékeny igéreteknek, - írja Döbrentei jelentésében -, de csak levél sem jött onnan” (JANCSÓ 1944: 112). Majd amikor Segesváron is hasonlóan bánnak vele, jelentésében nem titkolja véleményét „Nem kételkedem Binder Pál György szavában, de hogy ezen Nagyszebeni és Segesvári egészen elhallgatás a Szász nemzetnek a magyar nyelv elleni ismeretes mostani szegülése szempontjából ne jőne, nem lehet. Mintha félnének, hogy oly tanú iratokat adnak ki hiteles másolatban levéltáraikból, mik napfény világosságával ismertetik meg enmagukkal, miképen kivált a mostani Erdélyi országgyülésen a Magyar és Székely nemzet a nemzeti nyelvre nézve” csak azt akarja visszaállítani, ami Erdélyben a szászoknál is „másfél száz éven felül élt országos divatban”. Döbrentei szerint a szászok nem szeretnének kiadni levéltáraikból olyan bizonyítékokat, amelyek szerint ők , egykor legkészebben, legalább minden ellenmondás nélkül elfogadták” a magyar nyelvet hivatalos használatra is, ,s a magyar nyelv tudása és az azzal élés mellett saját nyelvük is fenn tuda maradni." Döbrentei végül kéri a Társaságot, hogy a szászok eme furcsa és udvariatlan eljárása ügyében tegyen valamit, érezzék a szász hatóságok, hogy a nála lévő érdekes iratokat ki kell adnia (JANCSÓ 1944: 113).

1840-ben a kisgyülés ajánlásokat készít a szerkesztőnek: 1. A szerkesztő előszavai, bevezetései, jegyzetei, szókivonatai a továbbiakban is a saját felelősségére mehet sajtó alá. 2. Minden, nem a szerkesztó által írt kisebb vagy nagyobb értekezést, bevezetést be kell mutatni a kis- vagy a nagygyülésnek. 3. Szerkesztő és a bíráló is adjon ki véleményt, hogy önállóan vagy a gyüjteményben adják-e ki a müre vonatkozó tanulmányt.

1840-ben megjelent a 2. kötet is: 1. Kinizsy Pálné Magyar Benigna imádságoskönyve (Czeh-kódex) 1513. 2. Vegyes tárgyú magyar iratok 1342-1599.

A kötet kiadásának van egy sajtótörténeti érdekessége is. A könyv ugyanis kétféle változatban került forgalomba. A második részben a vegyes iratok időrendben követik egymást, de jó néhány kötetben ez három helyen is megszakad: a 21-2. lapon, a XXV. számú nyelvemléknél, a 29-30. lapon a XXXI. számúnál és a 39-52. lap között többször is. Feltünő továbbá az is, hogy a leveleket sorszámuk mellett A és B betükkel is jelöli. Ha azonban a tartalomjegyzéket vagy a magyarázó jegyzeteket nézzük, egyértelmüen ezekre az időrenden kívüli iratokra vonatkoznak. 
Vannak azonban olyan kötetek is, ahol a nevezett helyeken teljesen más leveleket találunk, amelyek időrendben illeszkednek a többihez, de sem a tartalomjegyzékben, sem pedig a magyarázó jegyzetekben nem szerepelnek. A jelenségre RADÓ POLIKÁRP a következő magyarázatot adta: DöBRENTEI elöször a nyelvemlékeket nyomtatta ki sorjában, és csak utána a tartalomjegyzéket és a magyarázatokat. Vélhetően valaki megnézte a nyelvemlékeket, és figyelmeztette a szerkesztőt, hogy azok az iratok már megjelentek Sylvester János Új Testamentumában. Mentve a menthetőt, kicserélte az iratokat, korrigálta a jegyzeteket és a tartalomjegyzéket. Azonban így is elég sok változat-példány került ki a nyomdából, és a többféle könyvtárban megforduló érdeklődő legnagyobb megrökönyödésére az egyik könyvben nem azt találja, mint a másikban (RADÓ 1947: 153-156).

DÖBRENTEI is megemlíti ezt a cserét, de nem kapunk kielégítő magyarázatot a dologra.

Még megjelent a 3. kötet 1842-ben, a Tatrosi másolat 1466-ból (Müncheni kódex) és a Vegyes tárgyú magyar iratok 1540-1600, de a 3. kötet megjelenése után megtorpan a kiadvány munkálata. Döbrentei még igyekszik, anyagot gyüjt, de Toldy [Schedel] Ferenc titkár beszámolójából kitünik, hogy elsősorban az anyagiakon múlik a folytatás: ,[...] Mindezek nevelik ilyekben már is gazdag kézirattárunkat, s gazdagítanák nyomtatásban megindúlt nyelvemlék-gyüjteményünket is, nyelvészeink és történetbúváraink egyformán nagy hasznára, ha a vevő közönség nagyobb részvéte a sebes folytatást lehetővé tenné" (MTTÉvk. 8: 8-9).

4. A szabadságharc alatt és az azt követő időszakban háttérbe került a nyelvemlékkiadás. Döbrentei halála után Toldy Ferencet bízza meg az Akadémia a negyedik kötet befejezésével. A kötet első felét, a Guary-kódexet még 1846-ban kinyomtatta Döbrentei, de a másik fele és a bevezetés - mire mint készre hivatkozott a szerkesztő - sem kinyomtatva, sem kéziratban nem került elö. Toldy sem fejezte be az Egyházi vegyes könyv (Winkler-kódex) sajtó alá rendezését, a 4. kötet lezárása elött az 5. kötetet, a Jordánszkykódexet nyomtatta ki, de halála miatt ismét csak töredékes könyvek maradtak. Végül Volf Györgyre bízták a két kötet lezárását. A 4. kötet a Guary- és a Winkler-kódexet tartalmazza, az 5. pedig a Jordánszkyt. Mindkettő 1888-ban jelent meg.

A nyelvemlék-sorozat bírálói leginkább a hibás olvasatokat, a rossz keltezést róják fel Döbrenteinek. Az RMNy. hibái nagyrészt a kor tudományosságának színvonalából és szemléletéből, valamint a technikai lehetőségeikből származnak. Az elmélet, a nyelvemlékkiadás módszertana azonban a mai viszonyok között is megállja a helyét.

Döbrentei forráskiadói munkásságának Toldy Ferenc és az Akadémia méltó módon állított emléket. Még Kazinczy írt egy kódexről 1819-ben a Tudományos Gyüjtemény hasábjain, amelyet a gyulafehérvári Batthyaneumban őriztek. A Halábori Bertalan keze írásával lejegyzett kódex 150 zsoltárt, az Énekek énekét, Jób könyvének részleteit, evangéliumi darabokat, valamint episztolákat és prédikációkat tartalmazott. 1833-ban Döbrentei ugyan lemásoltatta, de nem tudta megjelentetni. Csak jóval később, 1884-ben a Nyelvemléktár 12. köteteként, Volf György adta ki, Döbrentei-kódex néven.

Döbrentei halála után az Akadémia 1851. május 10-ei ülésén áttekintették az addig elvégzett munkát, és a Leveles Tárat, amelyből a 2. és a 3. kötetben is jelentek meg részletek, így méltatta Toldy Ferenc: „,valódi kincstára a’ magyar nyelv’ külső történetének, melly körül a' boldogultnak többet köszönhetni, mint bárki másnak; mind a' magyar nép' belső élete' ismeretének" (TOLDY 1851: 14). 
Kulcsszók: reformkor, nyelvemlékkiadás, Magyar Tudós Társaság, Döbrentei Gábor, Régi Magyar Nyelvemlékek, forrásközlési elvek, névmagyarosítás.

\section{Hivatkozott irodalom}

ABAFFY CSILla 2000. Magyar nyelvemlékek és másolataik az MTAK kézirattárában. Magyar Könyvszemle 116: 340-351.

BALÁZS GÉZA 2006. A budai dülőkeresztelő. Napút 8/4: 73-78.

BÁRCZI GÉZA 1961. Hozzászólás a történeti forráskiadások kérdéséhez. Magyar Nyelv 57: 413-418. BENEDEK MARCELL szerk. 1963. Magyar Irodalmi Lexikon 1-2. Akadémiai Kiadó, Budapest.

DÖBRENTEI GÁBOR 1844. Visszamagyarodás Budapesten. Honderü 2: 2/2: 141-142, 335-336.

DÖBRENTEI GÁBOR 1845a. Visszamagyarodás Budapesten. Honderü 3: 1/2: 489-491.

DÖBRENTEI GÁBOR 1845b. Visszamagyarodás Budapesten. Honderü 3: 2/2: 21-23.

GORZÓ GELLÉRT 1914. Döbrentei Gábor és a jászóvári premontreiek viszonya a régi magyar nyelvemlékek ügyében. Remény Nyomda, Jászó.

JANCSÓ ELEMÉR 1944. Döbrentei Gábor élete és munkássága. Különnyomat. Minerva, Kolozsvár. JENEI FERENC 1959. Adalék a „Régi Magyar Nyelvemlékek” történetéhez. Magyar Nyelv 55: 520-521.

KISS JENŐ 2006. Döbrentei Gábor és a magyar nyelv ügye. Magyar Nyelvőr 130: 8-13.

KONCZ JÓZSEF 1897. Döbrentei Gábor levele Bolyai Farkashoz. Irodalomtörténeti Közlemények 7: 449-451.

MTTÉvk. 1.= A Magyar Tudóstársaság Évkönyvei 1. 1831-1832. Magyar Tudós Társaság, Pest, 1833. MTTÉvk. 2. = A Magyar Tudóstársaság Évkönyvei 2. 1832-1834. Magyar Tudós Társaság, Buda, 1835. MTTÉvk. 3. = A Magyar Tudóstársaság Évkönyvei 3. 1834-1836. Magyar Tudós Társaság, Buda, 1837. MTTÉvk. 4. = A Magyar Tudóstársaság Évkönyvei 4. 1836-1838. Magyar Tudományos Akadémia, Buda, 1840.

MTTÉvk. 8. = A Magyar Tudóstársaság Évkönyvei 8. 1845-1847. Magyar Tudományos Akadémia, Buda, 1860.

PAPP LAJOS 1991. A magyar nyelvemlékkiadás szemléleti változásai. In: KISS JENŐ - SzŰTS LÁSZLÓ szerk., Tanulmányok a magyar nyelvtudomány történetének témaköréböl. Akadémiai Kiadó, Budapest. 509-515.

[PETRICHEVICH HoRVÁTH LÁZÁR] 1847. Heti Szemle. - A budai hegyek ünnepélyes keresztelője... Honderü 5. 1/1: 499.

POGÁNY IRÉN 1969. Hozzászólás Buda magyar dűlőneveinek kérdéséhez. Magyar Nyelv 65: 204-207. POGÁNY IRÉN 1973. Epilógus a budai dülőnevekhez. Magyar Nyelv 69: 192-197.

RADÓ POLIKÁRP 1947. A Régi Magyar Nyelvemlékek II. kötetének változata. Magyar Nyelv 43: $153-156$.

RÉCSEY VIKTOR 1899. Kalászat a pannonhalmi kézirattárból. Döbrentei Gábor levelei Szeder Fábiánhoz. Irodalomtörténeti Közlemények 9: 479-484.

SZABÓ DÉNES 1948. Jegyzetek hasonmáskiadásban megjelent nyelvemlékek paleográfiailag hü közzétételének módjához. Magyar Nyelv 44: 128-132.

SZENTPÉTERY JÓzSEF főszerk. 2000. Magyar Kódex 4. Kossuth Kiadó, Budapest.

SZINNYEI JÓZSEF 1893. Magyar írók élete és munkái 2. (Caban-Exner). Hornyánszky, Budapest.

TOLDY FERENC 1851. Döbrentei Gábor' nyelvemlék-gyüjtéseiről. Új Magyar Múzeum 2/2: 13-14.

VÁCZY JÁNOS 1911. Kazinczy Ferenc levelezése 21. kötet (1829. január 1. - 1831. augusztus 20.). Magyar Tudományos Akadémia, Budapest.

VÁNYI FERENC szerk. 1926. Magyar Irodalmi Lexikon. Studium, Budapest.

VÉRTESY MiKLÓs 1972. A budai hegyvidék és Döbrentei Gábor. Budapest 10/2: 100. http://apps. arcanum.hu/app/budapest/view/Budapest_1972/?pg=99\&layout=s (2018. 10. 31.)

VISZOTA GYULA 1916. Széchenyi első négy művének nyelvéről. Magyar Nyelv 12: 49-63, 103-113. 


\section{From the history of the publication of early Hungarian texts in the 19th century}

\section{Gábor Döbrentei and Early Hungarian Linguistic Records}

The pursuit of independence that was characteristic of the reform age in Hungary foregrounded the issue of language. The Hungarian Learned Society, founded in 1830, gave institutional support to the cultivation of Hungarian: it defined it first and most important task as cultivation of the national language. In 1832 it was decided that latent old manuscripts should be collected so that obsolete Hungarian words and constructions can be rescued and revealed. It was decided that manuscripts hidden in Hungarian libraries should be found, original documents should be collected and published in sourcebooks in order to make a thorough exploration of the history of Hungary possible. The collected documents were first published in a series of volumes entitled Early Hungarian Linguistic Records. Gábor Döbrentei was appointed compiler and editor of the series in 1934. Volume One was published in 1838, Volume Two in 1840, and Volume Three in 1842. The last two volumes were completed and published in 1888 by György Volf. The way those early texts were presented, the principles of text processing are still pertinent today, even though errors do occur in the texts. The appreciation of Gábor Döbrentei (1785-1851), former secretary general of the Hungarian Academy of Sciences, literary organizer, translator, and writer, is equivocal within the history of Hungarian literature. His most renowned accomplishment is his share of the collection of early Hungarian documents; but he was also active as a language reformer: he coined a large number of new words and had an important role in the Hungarianization of geographical names of the hilly area around Buda.

Keywords: Hungarian age of reforms (1825-1848), publication of early Hungarian texts, Hungarian Learned Society, Gábor Döbrentei, Early Hungarian Linguistic Records, principles of source publication, Hungarianization of names.

TERBE ERIKA

ELTE Eötvös Loránd Tudományegyetem

\section{A névföldrajzi kutatások magyar eredményeiből*}

1. A névföldrajz fogalma. A névföldrajz a névtípusok vagy egyes nevek földrajzi elterjedését, jellemzőit vizsgáló szakterület, amely nagyon szoros kapcsolatot ápol a nyelvföldrajzzal (1. FARKAS 2014: 15; N. FODOR 2014b; HAJDÚ 2010b: 9; HOFFMANN 2003: 206; JUHÁSZ 2010: 31). Célja egyúttal „,névrendszerünk összefüggéseinek felderítése" (KÁZMÉR 1970: 12). Tartalma és feladatköre tágabban értelmezve minden olyan jelenség térbeliségének a vizsgálata, amelynek ,hordozója tulajdonnév, legyen az hangtani, alaktani, lexikai, szemantikai, netán régi helyesírási jellemző, vagy nyelven kívüli természeti, társadalmi entitás, amelyre a név valamilyen formában utal" (JUHÁsz 2010: 31). KÁZMÉR MiKLÓs a névföldrajznak három irányát különítette el, melyek az alábbiak: 1. Nyelvtörténeti (nyelvjárástörténeti) érdekü névföldrajz, amikor a nyelvtörténeti vizsgálatok korpuszába vonják be a neveket, és alaki szempontok szerint aktív vizsgálati

${ }^{*}$ A dolgozathoz nyújtott értékes észrevételeiért köszönettel tartozom FARKAS TAMÁSnak és JuHÁsz DEZSŐnek. 